\title{
Correction to: Modeling the effects of land cover change on sediment concentrations in a gold-mined Amazonian basin
}

\author{
Camila Andrade Abe ${ }^{1} \cdot$ Felipe Lucia Lobo ${ }^{2}$ Evlyn Márcia Leão de Moraes Novo ${ }^{1}$. Maycira Costa ${ }^{3} \cdot$ Yonas Dibike $^{4}$
}

Published online: 4 July 2019

(C) Springer-Verlag GmbH Germany, part of Springer Nature 2019

\section{Correction to: Regional Environmental Change} https://doi.org/10.1007/s10113-019-01513-8

The article which was recently published contained error. The second given names "Andrade" and "de Lucia" were captured as particles. Given in this article is the correct naming of authors.

The original article has been corrected.

Publisher's note Springer Nature remains neutral with regard to jurisdictional claims in published maps and institutional affiliations.

The online version of the original article can be found at https://doi.org/ 10.1007/s10113-019-01513-8

\section{Camila Andrade Abe}

camilabe@gmail.com

1 Remote Sensing Division, National Institute for Space Research (INPE), Avenida dos Astronautas, 1758 - Jardim da Granja, São José dos Campos, SP 12227-010, Brazil

2 Centre for Technological Development (CDTec), Federal University of Pelotas (UFPel), Pelotas, RS, Brazil

3 Spectral Lab, Department of Geography, University of Victoria, Victoria, BC, Canada

4 Environment and Climate Change Canada, Water and Climate Impacts Research Centre (W-CIRC), University of Victoria, Victoria, BC, Canada 